\section{Isolation, Characterization and Genetic Studies on Isolates of Phosphate Solubilizing Bacteria in Egyptian Calcareous Soils}

Keywords: Phosphate solubilizing bacteria; Phosphate uptake plant growth promoting traits; 16s rDNA; Phylogenetic and calcareous soils

\section{Abstract}

Phosphorous $(\mathrm{P})$ is an essential nutrient element and plays an important role in plant growth and development, it mostly presented in form unavailable for plants. Phosphate Solubilizing Bacteria (PSB) can be successfully used for solubilizing such forms rendering them available for plants. Thirty-two PSB strains were isolated on a Pikovskaya (PKV) agar medium containing Tricalcium Phosphate (TCP) and examined for plant growth promoting effects. A high portion of isolates $(68.8 \%)$ produced Indole Acetic Acid (IAA) in contents ranging from 5 to 15 $\mathrm{ugmL}^{-1}$ and $12.5 \%$ produced salicylic acid (SA) in contents $<100 \mu \mathrm{gmL}^{-1}$ while $50.0 \%$ fixed gaseous $\mathrm{N}_{2}$ nitrogen in medium deprived completely of nitrogen. A portion of $28.1 \%$ produced cellulose enzyme and $15.6 \%$ produced chitinase enzyme. In vitro tests showed that isolates were capable in controlling some fungus plant pathogens and isolates were resistance to some adverse conditions involving $\mathrm{pH}$, temperature and salinity. Use of $16 \mathrm{~s}$ rDNA analysis and other procedures showed that the most 3 effective isolates were Bacillus megaterium-MHI42578, Acinetobacter Iwoffii-MH142579 and Acinetobacter Iwoffii-MH142580. The results of cluster analysis (Similarity index) showed that were high and low similar values between the bacterial genera under studies.

\section{Introduction}

Phosphate $(\mathrm{P})$ is one of the most important elements for plant growth. Although it is abundant in soils in both organic and inorganic forms, its availability is limited to plants as it presents mostly in insoluble forms [1]. Chemical fertilizers are added to the soils, plants can only utilize few amounts of phosphoric fertilizers, which are quickly converted into insoluble forms. Consequently, chemical fertilizers are frequently applied during crop planting, but its regular use is costly and produces undesirable environmental impacts, such as soil and water contamination. Therefore, $\mathrm{P}$ is often regarded a limiting nutrient in agricultural soils [2,3]. Soil microorganisms play a great role in availability of phosphate to plants [4].

Biofertilizers are considered to be the alternate source to meet the nutrient requirement of crops and to bridge the future gaps. Soil microorganisms which can solubilize phosphorus, fix atmospheric nitrogen or stimulate plant growth through synthesis of growth promoting substances could be used as safe alternative for the overuse of harmful agrochemicals [5-7]. Soil microorganisms play a great role in availability of phosphate to plants [8]. Microorganisms have the capacity to solubilize Phosphate, These include bacteria, fungi, actinomycetes and algae, and they are collectively called as Phosphate Solubilizing Microorganisms. Bacteria are more successful in $\mathrm{P}$ solubilization than others. The Plant Growth Promoting Rhizobacteria (PGPR) include Phosphate solubilizing bacteria $[9,10]$.
Journal of

Plant Biology \& Soil Health

Abdelaziz $\mathrm{S}^{1 *}$, Hemeda $\mathrm{NF}^{2}$, Belal $\mathrm{EE}^{3}$ and Serag $\mathrm{AM}^{4}$

${ }^{\prime}$ Department of Agricultural Microbiology, Fayoum University, Egypt

${ }^{2}$ Department of Genetics, Fayoum University, Egypt

${ }^{3}$ Department of Soils and Water, Fayoum University, Egypt

${ }^{4}$ Department of Genetics and Genetic Engineering, Benha University, Egypt

Address for Correspondence

Abdelaziz S, Faculty of Agriculture, Department of Agricultural Microbiology, Fayoum University, Egypt, E-mail: sa171@fayoum.edu.eg

Submission: 10 January, 2019

Accepted: 13 Februay, 2019

Published: 15 Februay, 2019

Copyright: ๑ 2019 Abdelaziz S, et al. This is an open access article distributed under the Creative Commons Attribution License, which permits unrestricted use, distribution, and reproduction in any medium, provided the original work is properly cited.

Consequently, the present work aims to study the prevalence of the phosphate solubilizing bacteria in various soils of Fayoum governorate, isolation of some individuals and studying some of their characters and activities $\left(\mathrm{N}_{2}\right.$-fixation, siderophores, Salicylic Acid (SA) and Indole Acetic Acid (IAA) production. The capability of these isolates in controlling some plant pathogenic fungi (in vitro) was also determined. The resistibility of isolates to some adverse conditions prevailing in our conditions ( $\mathrm{pH}$, temp. and salt content) was also included. The isolates were identified by using $16 \mathrm{~s}$ rDNA analysis after DNA bacteria isolation and the most 3 effective isolates Bacillus megaterium-MH142578, Acinetobacter lwoffi-MH142579 and Acinetobacter lwoffi-MH142580 were involved on proceeding study. Generally strains of PSB have plant growth-promoting activities and antagonistic potential against phytopathogenic fungi that could be used as alternate source for the overuse of harmful agrochemicals.

\section{Materials and Methods}

\section{Collection and characterization of soils samples}

Soil samples were collected from two sites distinguished by calcareous soils conditions, site 1 in Youssef El-Sediek and site 2 in Domo in Fayoum Governorate area; surface soil sample $(0-30 \mathrm{~cm})$ was collected from the two sites. Collected soil samples were airdried, gently crushed and passed through a $2 \mathrm{~mm}$ sieve and stored in plastic bottles. Some physical and chemical properties of the soil were analyzed. Particle size distribution of the collected soil samples were carried out by the international pipette method [11]. Soil texture class was obtained. The $\mathrm{pH}$ values of soil samples were measured in the saturated soil paste using Bekman $\mathrm{pH}$ meter also Electrical conductivity values were determined in the saturated soil-water paste extract as $\mathrm{dS} / \mathrm{m}$, using CM25 conductivity meter [12]. Total calcium carbonates were determined using Collinś Calcimeter [13]. Soil organic matter contents were determined using the wet combustion method according to Walkly and Black ś method [14]. Total nitrogen was determined using micro-kjeldahl method [15]. Available potassium was extracted using $1.0 \mathrm{~N}$ ammonium-acetate solution at $\mathrm{pH} 7.0$ [12]. Available $\mathrm{P}$ was extracted with sodium bicarbonate 
$0.5 \mathrm{~N}\left(\mathrm{NaHCO}_{3}\right)$ solution at $\mathrm{pH} 8.5$ [16]. Available micronutrients (Fe, $\mathrm{Mn}, \mathrm{Zn}$ and $\mathrm{Cu}$ ) were extracted by DTPA solution [17]. Then measured with Inductively Coupled Plasma (ICP) atomic emission spectroscopy.

\section{Isolation of phosphate solubilizing bacteria}

Ten grams of each soil sample was suspended in $90 \mathrm{ml}$ sterile saline solution and was shaken for $1 \mathrm{~h}$. The serially diluted soil samples were placed on Petri dishes containing Pikovskaya's (PKV) agar medium by pour plate technique and incubated at $28 \pm 2{ }^{\circ} \mathrm{C}$ for 48-96 $\mathrm{h} \mathrm{[18].} \mathrm{The} \mathrm{bacterial} \mathrm{colonies} \mathrm{showing} \mathrm{clear} \mathrm{zone} \mathrm{around} \mathrm{them}$ were considered as Phosphate Solubilizing Bacteria (PSB) as shown in [19] (Figure 1). Pure culture of the isolates was made by repeated sub culturing for 2-3 times on fresh PKV plate and was maintained on PKV slants at refrigerator temperature.

\section{Assay of solubilization index (SI)}

To determine the Solubilization Index (SI), the sterilized Pikovskaya's (PKV) agar medium was poured into sterilized Petri plates, containing insoluble $\mathrm{Ca}_{3}\left(\mathrm{PO}_{4}\right)_{2}$ at $5 \mathrm{~g} / \mathrm{L}^{-1}$. After solidification of the media, the plates were inoculated with the isolated bacteria, incubated at $28 \pm 2{ }^{\circ} \mathrm{C}$ for two weeks and assayed visually. The solubilization index was determined by measuring the halo (clear zone) diameter and the colony diameter, using the following formula [20]. All assays were replicated three times.

\section{$\mathrm{SI}=\frac{\text { Colony diametere }+ \text { Halozone diameter }}{\text { Colony diametere }}$}

Morphological, physiological and biochemical characters of isolates

Different morphological characters of isolates obtained were observed on NB agar media incubated for 48 hours at $30{ }^{\circ} \mathrm{C}$. Cell shape was examined microscopically using gram stain in addition to

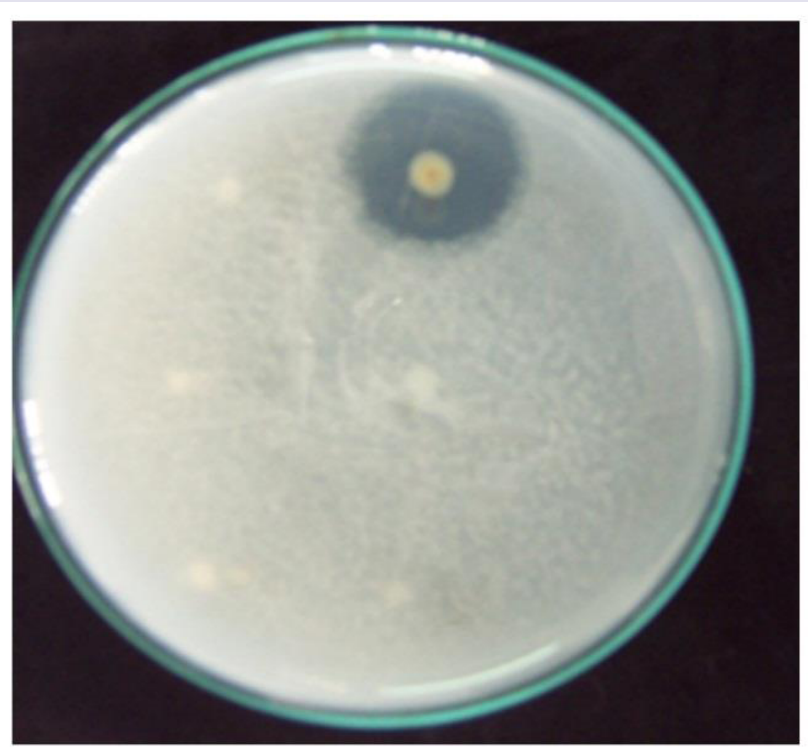

Figure 1: Isolation of Phosphate solubilization bacteria.

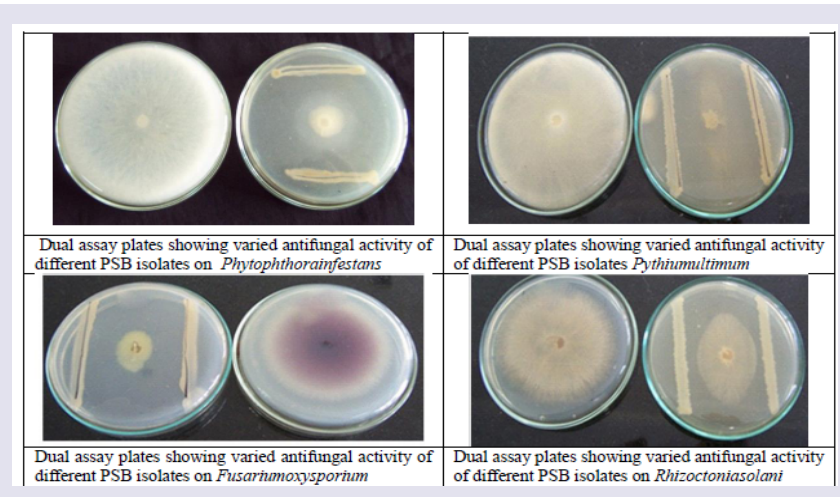

Figure 2: Antifungal activity assay.

motility. Catalase and oxidase activities were measured also.

\section{Characterization of plant growth prompting traits}

The capability to produce Plant Growth Promoting substances (PGPs) such as Indoleacetic Acid (IAA) production was measured by the colorimetric method [21], Siderophores production by different isolates was detected using the method described by Schwyn with several modification by Pallai $[22,23]$. Salicylic acid (SA), isolates were grown at $28^{\circ} \mathrm{C}$ for $48 \mathrm{~h}$ on a rotary shaker at $200 \mathrm{rpm}$ in flasks containing $25 \mathrm{ml}$ of the standard succinate medium, the absorbance of the purple iron-SA complex developed in the aqueous phase was measured at $527 \mathrm{~nm}$, using SA dissolved in the growth medium and treated as described above as a control [24, 25]. Cellulose production was visualized by flooding the cellulose decomposition medium plates with $0.1 \%$ (w/v) Congo red for 15 to $30 \mathrm{~min}$ followed by bleaching the plates with $1 \mathrm{M} \mathrm{NaCl}$, according to the method of [26]. Chitinase production was assessed qualitatively by a microbiological method based on growth of isolates in chitinase medium amended with colloidal chitin [27]. The isolates were screened in vitro for $\mathrm{N}_{2}$ fixation by growing them on plates of $\mathrm{N}$-free agar medium for $48 \mathrm{~h}$ at $28^{\circ} \mathrm{C}$. The isolates that grow after being sequentially transferred 10 times to the same medium were considered presumptive positive for $\mathrm{N}_{2}$ fixation [28-30].

\section{Antifungal activity assay}

Phosphate Solubilizing Bacteria (PSB) isolates were screened in vitro for antagonism towards four soil borne pathogenic fungi: Pythium ultimum, Rhizoctonia solani, Fusarium oxysporum and Phytophthora infestans in dual culture test [31]. Five $\mu \mathrm{l}$ of an exponentially growing bacterial culture was streaked along two opposite sides of surface-dried Potato Dextrose Agar (PDA) plates. Plates subsequently incubated at $28{ }^{\circ} \mathrm{C}$ for $24 \mathrm{~h}$. Following bacterial growth, mycelial agar disc of 5-mm-diameter from a 7-day-old culture from the target fungi grown on PDA plate was placed in the center of the plate between the two parallel streaks of the test bacteria. Plates inoculated with target fungi alone served as control plates, and two replicate plates were used for each bacterial isolate. Plates were then incubated at $25^{\circ} \mathrm{C}$ for 7 days. In vitro antagonistic activity was assessed by relating mycelial diameter on plates inoculated with bacteria to mycelial diameter on control plates and computing percentage inhibition as shown in (Figure 2). 
Citation: Abdelaziz S, Hemeda NF, Belal EE, Serag AM. Isolation, Characterization and Genetic Studies on Isolates of Phosphate Solubilizing Bacteria in Egyptian Calcareous Soils. J Plant Biol Soil Health. 2019;6(1): 10.

Effect of $\mathrm{pH}$, temperature and salt content on growth of selected strains

The PSB isolates were examined against some adverse environmental conditions to determine their capability to live, proliferate sustain life and perform their activities. They were tested against temperature, increasing $\mathrm{pH}$ and salt tolerant characters which prevail in our conditions. They were inoculated at fixed counts on 100 $\mathrm{ml}$ complete nutrient broth medium in $250 \mathrm{ml}$ flasks which incubated for 24, 48 and 72 hours at elevated $\mathrm{pH}$, temperature and salt content. Each character was studied separately and in combination with one or two of the other characters. Each treatment was replicated three times.

\section{Genotypic characterization by 16s-rDNA}

\section{Bacterial DNA extraction and PCR amplification}

The nucleic acid was extracted using protocol of beat beading with zirconia silica beads combined with ABT genomic DNA mini extraction kit spin column (Applied biotechnology, Egypt) according to the manufacture's instruction. A 16s rDNA reference was considered as full-length if it covered the position of the primer (27 F 5'-AGAGTTTGATCCTGGCTCAG-3' and $1492 \mathrm{R}$ 5--GGTTACCTTGTTACGACTT-3'), used in a previous study [32]. The PCR was performed in the thermal cycle 2720 (Applied Biosystem, USA) in a total volume of $25 \mu \mathrm{l}$ containing $1 \mu \mathrm{l}$ of each primer, $200 \mu \mathrm{M}$ from the four ribonucleotide triphosphates (dNTPs), $5 \mu \mathrm{l}$ of 10X PCR buffer, $1 \mu \mathrm{l}$ of $25 \mathrm{~m} \mathrm{~mol} \mathrm{Mgcl}_{2}, 1 \mu$ of template DNA, $1 \mu \mathrm{l}$ of Taq DNA polymerase and $14.5 \mu \mathrm{l}$ of water nuclease-free.

Amplification of DNA was carried out under the following conditions: denaturation at $94{ }^{\circ} \mathrm{C}$ for 5 min followed by 30 cycles of $94{ }^{\circ} \mathrm{C}$ for $30 \mathrm{~s}, 52{ }^{\circ} \mathrm{C}$ for $30 \mathrm{~s}, 72{ }^{\circ} \mathrm{C}$ for $1.5 \mathrm{~min}$ and final extension at $72{ }^{\circ} \mathrm{C}$ for $10 \mathrm{~min}$. PCR products of bacterial isolates were checked by electrophoresis with $1.8 \%$ agarose gel and stained by ethidium bromide and then visualized and photographed under UV transilluminator. The PCR have specific bands at size around $1500 \mathrm{bp}$. The amplified PCR product was purified using Montage PCR Clean up Kit (Millipore), following manufacture instructions to remove unincorporated PCR primers.

\section{Sequencing of 16s rDNA and Phylogenetic analysis}

The purified PCR products were subjected to sequencing through Solvent Sequencing Service located in Korea. The sequences of $16 \mathrm{~s}$ rDNA of the three bacteria isolates were submitted to GenBank.

The data of the nucleotide sequence of the ITS regions of rDNA obtained from the three isolates were compared with $16 \mathrm{~s}$ rDNA collected from Bacillus megaterium and Acinetobacter lwoffii sequences available in GenBank database (http://www.ncbi. nlm.nih.gov/ Blast). NCBI, Bethesda, MD, (USA) [33,34]. The 16s rDNA sequences of all bacterial isolates were aligned with reference sequences showing sequence homology from the NCBI database using Clustal omega multiple sequence alignment. Phylogenetic dendogram was constructed by the clustal omega multiple sequence alignment programs (successor of Clustal W [35]. Phylogenetic trees were constructed by the Un-weighted Pair Group Method with Arithmetic Mean (UPGMA).

\section{Results}

\section{Chemical and physical properties of the studied soils}

(Table 1) illustrates the available characters of the two samples collected from various locations distinguished by calcareous soils conditions. The soils Chemical and physical properties studied as calcium carbonates\%, pHe (in soil paste) ECe $\mathrm{dS} / \mathrm{m}$, organic matter contents\%, Total Nitrogen $\mathrm{mg} / \mathrm{kg}$ soil, available Phosphorus $\mathrm{mg} / \mathrm{kg}$ soil, available Potassium $\mathrm{mg} / \mathrm{kg}$ soil , available micronutrients such as (Fe, $\mathrm{Mn}, \mathrm{Zn}$, and $\mathrm{Cu} \mathrm{mg} / \mathrm{kg}$ soil). Soil texture classes of all samples were diverse between sand clay and sandy loam.

\section{Isolation of phosphate solubilizing bacteria (PSB) and determination of their characters}

Thirty-two bacterial isolates were obtained from two samples in PKV medium. The possible morphological and physiological characters of the isolates are summarized in (Table 2). The screened bacteria were able to solubilize TCP on solid culture state by forming clear halo zone, with different degree of solubilization, depending on the type of organism involved. However, all the selected isolates were found to be potent phosphate solubilizers showing clear halo zone around their colonies. Among of 32 potent isolates, strain NSE showed the maximum phosphate solubilization activity as visualized by the size of clear zone developed around the colony, which showed solubilization index of 5.00 as showed in the same table.

\section{Characterization of plant growth prompting traits}

The capability of isolates to produce some plant growth promoting traits was also determined as shown in (Table 3). A total 32 isolates which isolated from different samples tested as plant growth promoters bacteria $21(68.75 \%)$ of them were capable to produce IAA in detectable amounts (5 to $15 \mu \mathrm{g} / \mathrm{ml}$ ). Four isolates (12.5\%), out of total, produce salicylic acid in appreciable amounts $(>100 \mu \mathrm{g} / \mathrm{ml})$, while $13(40.62 \%)$ of them produce less than 100 $\mu \mathrm{g} / \mathrm{ml}$ and the rest cannot produce the compound. Concerning Siderophores (Sid), it was found that $20(62.5 \%)$ of the total PSB isolates able to produce Sid. The ability of different isolates to grow on $\mathrm{N}$-free medium (putative $\mathrm{N}_{2}$ fixers) was also examined in suitable liquid culture medium. The isolate capable of growing in medium free of any $\mathrm{N}$-source for ten successive subculture was considered as putative $\mathrm{N}_{2}$ fixer, whether the fixation was via $\mathrm{N}_{2}$-ase or by scavenging nitrogen from the surroundings. In this study, out of 32 isolates tested $16(50 \%)$ of isolates were able to grown on in free medium. Regarding lyticenzymes, among the enzymes tested number of cellulose producers were nine isolates $(28.12 \%)$.whereas chitinase-producers recorded five isolates (15.62\%).

\section{Antifungal activity assay}

Plant Growth Promoting Rhizobacteria (PGPR) has attracted the attention of many researchers because of the potential for developing these bacteria as inocula for plant disease control. Results presented in that $12(37.5 \%)$ of tested isolates had a wide range of antagonistic activity against $P y$. ultimum (Table 4), while about 17 (53.12\%), 20 (62.5\%) and 17 (53.12\%), against $R$. solani F. oxysporum and $P$. infestans respectively.

Assessment of the PSB isolates according to their in vitro traits 
Citation: Abdelaziz S, Hemeda NF, Belal EE, Serag AM. Isolation, Characterization and Genetic Studies on Isolates of Phosphate Solubilizing Bacteria in Egyptian Calcareous Soils. J Plant Biol Soil Health. 2019;6(1): 10.

ISSN: $2331-8996$

Table 1: Chemical and physical properties of the studied soils.

\begin{tabular}{|c|c|c|}
\hline Soil Properties & Site 1 & Site 2 \\
\hline Texture class & Sandy Clay & Sandy Loam \\
\hline Calcium carbonates, $\%$ & 32.2 & 10.8 \\
\hline $\begin{array}{l}\mathrm{PHe} \text { (in soil paste) } \\
\mathrm{ECe}, \mathrm{dS} / \mathrm{m}\end{array}$ & $\begin{array}{l}8.11 \\
10.5\end{array}$ & $\begin{array}{l}7.86 \\
4.70\end{array}$ \\
\hline Organic matter contents, $\%$ & 0.87 & 0.90 \\
\hline $\begin{array}{l}\text { Total Nitrogen, } \mathrm{mg} / \mathrm{kg} \text { soil } \\
\text { Available Phosphorus, } \mathrm{mg} / \mathrm{kg} \text { soil } \\
\text { Available Potassium, } \mathrm{mg} / \mathrm{kg} \text { soil } \\
\text { DTPA extractable }-\mathrm{Fe}(\mathrm{mg} / \mathrm{kg} \text { soil) } \\
\text { DTPA extractable }-\mathrm{Mn}(\mathrm{mg} / \mathrm{kg} \text { soil) } \\
\text { DTPA extractable }-\mathrm{Zn}(\mathrm{mg} / \mathrm{kg} \text { soil) } \\
\text { DTPA extractable }-\mathrm{Cu}(\mathrm{mg} / \mathrm{kg} \text { soil) }\end{array}$ & $\begin{array}{l}14.1 \\
2.56 \\
28.0 \\
2.19 \\
1.58 \\
0.68 \\
0.12\end{array}$ & $\begin{array}{c}14.8 \\
4.25 \\
42.57 \\
3.45 \\
2.25 \\
0.87 \\
0.15\end{array}$ \\
\hline
\end{tabular}

Table 2: Morphological and Physiological characters of PSB Isolates.

\begin{tabular}{|c|c|c|c|c|c|c|c|}
\hline Isolates & $\begin{array}{c}\text { Colony } \\
\text { ship }\end{array}$ & Cell ship & G-stain & Motility & Oxidase & Catalase & SI \\
\hline $\mathrm{NSE}_{1}$ & Circular & L. rod & + & + & + & + & 5.00 \\
\hline $\mathrm{NSE}_{2}$ & Circular & Short rod & - & - & - & + & 4.60 \\
\hline $\mathrm{NSE}_{3}$ & Circular & Short rod & - & - & - & + & 4.50 \\
\hline $\mathrm{NSE}_{4}$ & Circular & L. rod & + & + & + & + & 3.60 \\
\hline $\mathrm{NSE}_{5}$ & Punctiform & L. rod & + & + & + & + & 4.25 \\
\hline $\mathrm{NSE}_{6}$ & irregular & L. rod & + & + & + & + & 3.00 \\
\hline $\mathrm{NSE}_{7}$ & irregular & L. rod & + & + & + & + & 4.20 \\
\hline $\mathrm{NSE}_{8}$ & irregular & L. rod & + & + & + & + & 4.00 \\
\hline $\mathrm{NSE}_{9}$ & Circular & Short rod & - & + & + & + & 4.60 \\
\hline $\mathrm{NSE}_{10}$ & Circular & L. rod & + & + & + & + & 2.38 \\
\hline $\mathrm{NSE}_{11}$ & Circular & L. rod & + & + & + & + & 3.00 \\
\hline $\mathrm{NSE}_{12}$ & Circular & L. rod & - & + & + & + & 2.40 \\
\hline $\mathrm{NSE}_{13}$ & Circular & L. rod & + & + & + & + & 3.60 \\
\hline $\mathrm{NSE}_{14}$ & Circular & Short rod & - & - & - & + & 2.6 \\
\hline $\mathrm{NSE}_{15}$ & Circular & L. rod & + & + & + & + & 2.60 \\
\hline $\mathrm{NSE}_{16}$ & irregular & L. rod & + & + & + & + & 2.40 \\
\hline $\mathrm{NSE}_{17}$ & irregular & coccobacilli & - & - & - & + & 4.40 \\
\hline $\mathrm{NSE}_{18}$ & irregular & L. rod & + & + & + & + & 4.60 \\
\hline $\mathrm{NSE}_{19}$ & irregular & L. rod & + & + & + & + & 4.25 \\
\hline $\mathrm{NSE}_{20}$ & irregular & L. rod & + & + & + & + & 4.40 \\
\hline $\mathrm{NSE}_{21}$ & Circular & Short rod & - & + & + & + & 3.20 \\
\hline $\mathrm{NSE}_{22}$ & irregular & L. rod & - & + & + & + & 4.00 \\
\hline $\mathrm{NSE}_{23}$ & Circular & L. rod & + & + & + & + & 4.20 \\
\hline $\mathrm{NSE}_{24}$ & Circular & Short rod & - & + & + & + & 4.60 \\
\hline $\mathrm{NSE}_{25}$ & Circular & L. rod & + & + & + & + & 3.80 \\
\hline $\mathrm{NSE}_{26}$ & Circular & L. rod & + & + & + & + & 4.25 \\
\hline $\mathrm{NSE}_{27}$ & Circular & Short rod & - & + & - & + & 4.25 \\
\hline $\mathrm{NSE}_{28}$ & irregular & L. rod & + & + & + & + & 3.33 \\
\hline $\mathrm{NSE}_{29}$ & irregular & L. rod & + & + & + & + & 4.20 \\
\hline $\mathrm{NSE}_{30}$ & irregular & Short rod & - & - & - & + & 3.67 \\
\hline $\mathrm{NSE}_{31}$ & Circular & Short rod & - & - & - & + & 2.86 \\
\hline $\mathrm{NSE}_{32}$ & Circular & L. rod & + & + & + & + & 1.83 \\
\hline
\end{tabular}

SI: Solubilization Index; G-stain: Gram stain

\section{that might be associated with ability to function as PGPR}

In an attempt to select better bacterial isolates with high plant growth promotion potential, a bonitur scale similar to that described by Krechel was generated and used for assessment of PSB isolates [36] (Figure 3). In this scale, points were given to each bacterial trait in vitro determined within this study. Up to three points each were given for antagonistic activity toward each of the five indicator fungi, one point for each of the hydrolytic enzymes, and PNF, three points for IAA production, and Siderophores were given two points, one as antifungal trait and one for their use by plants for iron acquisition. This generated of bonitur scale of 21 points. As shown in (Table 5), results of the assessment revealed that out of the 32 isolates screened, $\mathrm{NSE}_{1}, \mathrm{NSE}_{2}, \mathrm{NSE}_{3}, \mathrm{NSE}_{20}$ and $\mathrm{NSE}_{26}$ isolates have the top three ranks according to assessment values.

The five isolates characterized by high efficiency in different activities according to assessment values were tasted effect of $\mathrm{pH}$, temperature and salt content on growth of strains under extreme conditions the results as shown in (Table 6).

The more efficient three strains $\left(\mathrm{NSE}_{1}, \mathrm{NSE}_{2}\right.$ and $\mathrm{NSE}_{3}$ ) were chosen to study their efficiencies in some important biological processes and activities. The activities studied were limited in $\mathrm{N}_{2}$ fixation ability, cellulose activity, indole acetic acid, siderophores and salicylic acid production. In addition, their inhibition capacity for the growth of four pathogenic fungi which mentioned before. Worth mentioning that the three strains had the same efficiency whether in extreme or in normal conditions.

\section{Molecular characterization and identification of bacterial isolates}

PCR amplification of ribosomal DNA was carried out with universal forward and reverse primers of $16 \mathrm{~s}$ rDNA and produced a fragment of approximately $1500 \mathrm{bp}$ (Figure 4). This size corresponded to the expected size as compared to other bacteria [37]. The variability within the amplified regions was investigated by phylogenetic analysis. The amplified PCR product was run on $1.8 \%$ agarose gel viewed under the UV transilluminator.

\section{Phylogenetic analysis of the rDNA sequences}

The amplified PCR product of representative isolates was identified and sequenced. A BLASTN analysis carried out through GenBank (http://www.ncbi.nlm.nih.gov) revealed that all the isolates were members of two different genera, Bacillus genus and the genus 
Citation: Abdelaziz S, Hemeda NF, Belal EE, Serag AM. Isolation, Characterization and Genetic Studies on Isolates of Phosphate Solubilizing Bacteria in Egyptian Calcareous Soils. J Plant Biol Soil Health. 2019;6(1): 10.

ISSN: $2331-8996$

Table 5: Assessment of phosphate solubilizing bacteria (PSB) isolates.

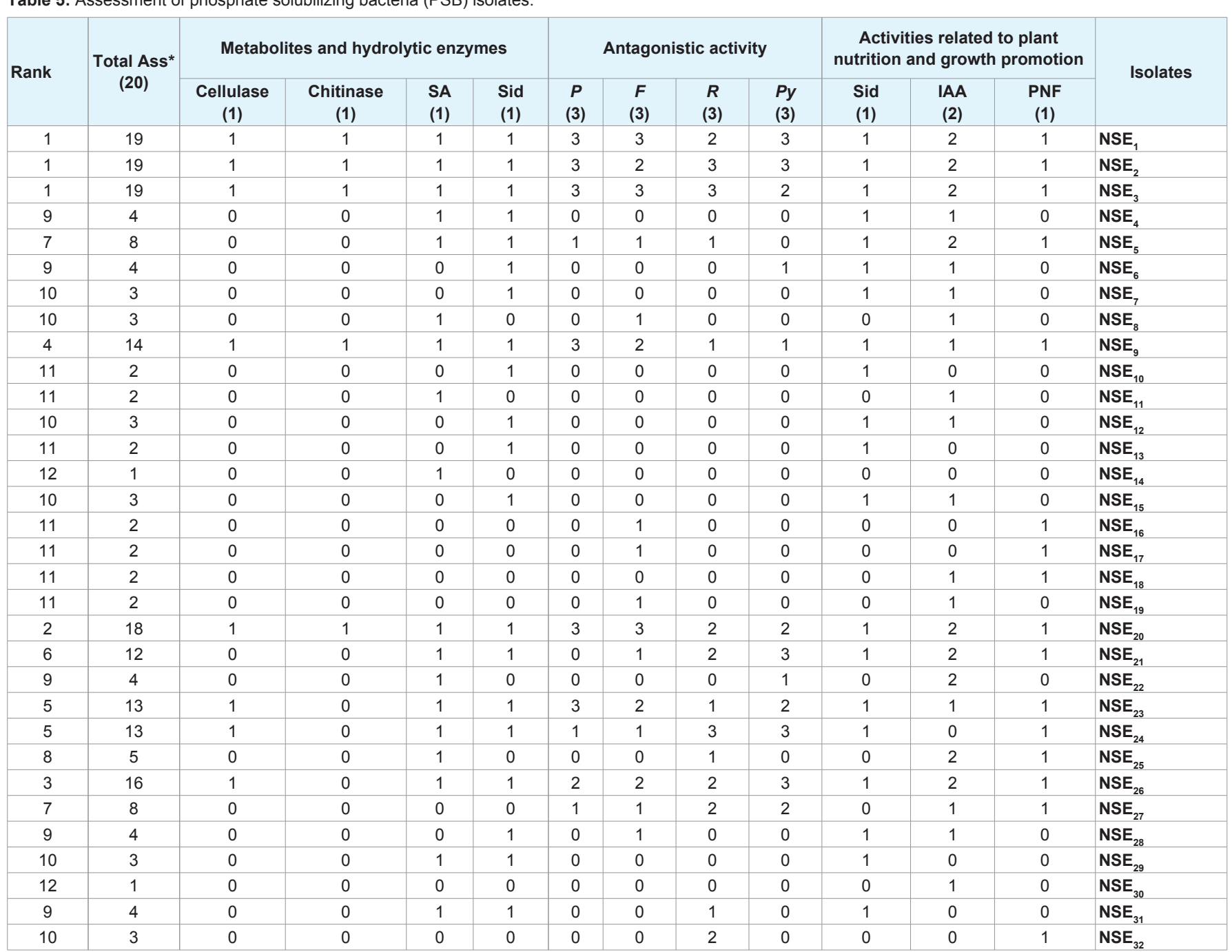

PNE = Putative $\mathrm{N}_{2}$-fixation, $-=0,+=1$

IAA = Indoleacetic acid, IAA, 1,2,3 according to color intensity

Sid $=$ Siderophores,

$\mathrm{SA}=$ Salicylic acid

$P y=$ Pythium ultimum, $R=$ Rhizoctonia solani, $F=$ Fusarium oxysporum, $P=$ Phytophthora infestans

Growth inhibition \% , 1= $30-49.9 \%, 2=50-69.9 \%, 3=>70$

Ass $=$ Assessment

Table 6: Effect of $\mathrm{pH}$, temperature and salt content on growth of selected PSB strains.

\begin{tabular}{|c|c|c|c|c|c|c|c|c|}
\hline \multirow{2}{*}{ Strain No. } & \multicolumn{4}{|c|}{$\mathrm{pH} 7.0$} & \multicolumn{3}{c|}{$\mathrm{pH} 10.0$} \\
\cline { 2 - 10 } & \multicolumn{2}{|c|}{$30^{\circ} \mathbf{C}$} & \multicolumn{2}{|c|}{$50^{\circ} \mathbf{C}$} & \multicolumn{2}{c|}{$30^{\circ} \mathbf{C}$} & \multicolumn{2}{c|}{$50^{\circ} \mathbf{C}$} \\
\cline { 2 - 10 } & $-\mathrm{s}$ & $+\mathrm{s}$ & $-\mathrm{s}$ & $+\mathrm{s}$ & $-\mathrm{s}$ & $+\mathrm{s}$ & $-\mathrm{s}$ & $+\mathrm{s}$ \\
\hline $\mathrm{NSE}_{1}$ & + & + & + & + & + & + & + & + \\
\hline $\mathrm{NSE}_{2}$ & + & + & + & + & + & + & + & + \\
\hline $\mathrm{NSE}_{3}$ & + & + & + & + & + & + & + & + \\
\hline NSE $_{9}$ & + & + & + & - & + & + & + & - \\
\hline NSE $_{24}$ & + & + & + & + & + & + & - & - \\
\hline
\end{tabular}

- $+\mathrm{S}+15 \%$ salt

- -S no salt

- Incubation period $72 \mathrm{~h}$

- Three replicates were used for each treatment.

In the present work, the 32 PSB isolates were screened for a wide array of traits that might be associated with ability to function as
Table 7: Identification of bacterial strains on the basis of $16 \mathrm{~s}$ rDNA gene sequence similarity.

\begin{tabular}{|c|c|c|}
\hline Strain code & Accession no. & Bacterial name \\
\hline NSE $_{1}$ & MH142578 & Bacillus megaterium \\
\hline NSE $_{2}$ & MH142579 & Acinetobacter /woffii \\
\hline NSE $_{3}$ & MH142580 & Acinetobacter /woffii \\
\hline
\end{tabular}

PGPR several bacterial strains have been reported to fix $\mathrm{N}_{2}$. Among of 32 PSB isolated in the present study [45-47], 16 (50\%) were found Presumptive Nitrogen Fixers (PNF). Indole Acetic Acid (IAA) is one of the most physiologically active auxins. IAA is a common product of L-tryptophane metabolism by several microorganisms including PGPR [48]. It is presumed that PGPR producing plant growth promoting agents play a critical role in plant growth promotion. In the present work, the $32 \mathrm{PSB}$ isolates were screened for their ability to 
Citation: Abdelaziz S, Hemeda NF, Belal EE, Serag AM. Isolation, Characterization and Genetic Studies on Isolates of Phosphate Solubilizing Bacteria in Egyptian Calcareous Soils. J Plant Biol Soil Health. 2019;6(1): 10.

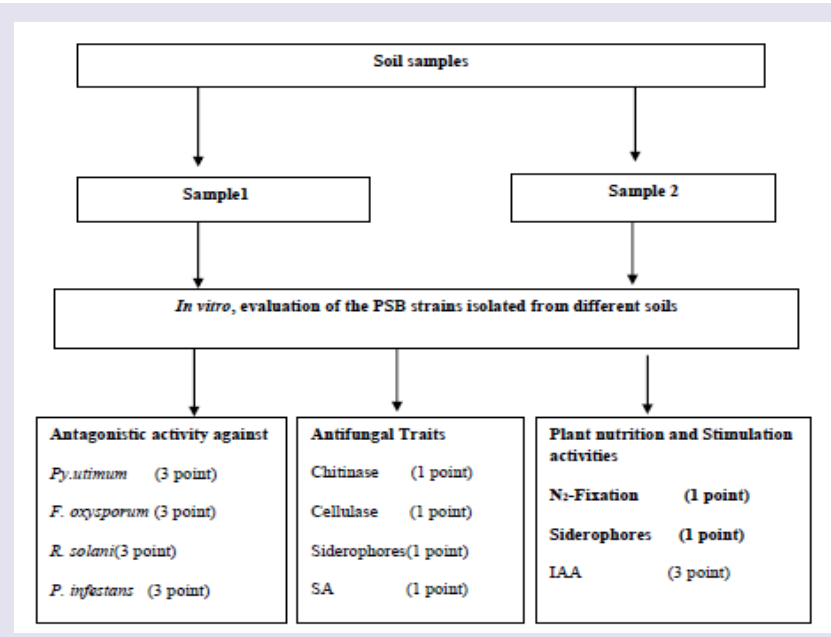

Figure 3: Aboniture scale $(\Sigma 20$ points) used for the assessment of the isolates based on their in vitro PGP traits screening.

Table 8: Genetic similarity percentage of 7 isolates of Bacillus megaterium and isolate NSE1 with accession number MH142578 based on ITS region of genomic 16 s rDNA gene.

\begin{tabular}{|l|c|c|c|c|c|c|c|c|}
\hline & $\mathbf{1}$ & $\mathbf{2}$ & $\mathbf{3}$ & $\mathbf{4}$ & $\mathbf{5}$ & $\mathbf{6}$ & $\mathbf{7}$ & $\mathbf{8}$ \\
\hline $\mathbf{1}$ & 100 & 98.12 & 98.12 & 98.12 & 98.12 & 98.12 & 98.12 & 98.12 \\
\hline $\mathbf{2}$ & & 100 & 98.83 & 99.38 & 98.77 & 99.52 & 99.31 & 99.72 \\
\hline $\mathbf{3}$ & & & 100 & 99.24 & 98.83 & 99.23 & 99.31 & 99.31 \\
\hline $\mathbf{4}$ & & & & 100 & 99.45 & 99.65 & 99.52 & 99.52 \\
\hline $\mathbf{5}$ & & & & & 100 & 99.38 & 99.17 & 99.31 \\
\hline $\mathbf{6}$ & & & & & & 100 & 99.72 & 99.58 \\
\hline $\mathbf{7}$ & & & & & & & 100 & 99.52 \\
\hline $\mathbf{8}$ & & & & & & & & 100 \\
\hline
\end{tabular}

1: |MH142578|NSE1* 2: |MG544100| B.megaterium, 3: MG430262| B.megaterium, 4: MG430259| B.megaterium,

5: |MG430255| B.megaterium, 6: |MG430252| B.megaterium, 7: |MG430250|

B.megaterium and 8: |MG430248| B.megaterium

produce IAA. Results presented in this study show that $68.5 \%$ of the PSB isolates produced detectable levels of IAA in culture supernatants. These isolates varied greatly in their ability to produce IAA.

It was reported that the ability of bacterial strains to antagonize pathogenic fungi was related to the production of extracellular siderophores which deprive phytopathogenic microflora of iron, thus limiting their growth $[49,50]$. It was reported that plants use microbial Sid for iron acquisition [51], and Sid is among factors involved in ISR [52,53]. Concerning Siderophores (Sid), it was found that a $25 \%$ of the total PSB isolates able to produce Sid.

With regard to SA, the data showed that ability to produce SA appears to be widespread among the PSB isolates. More than half of isolates (53\%) were able to produce SA. Many studies indicated that SA plays an important role in plant defense response against pathogen attack and is essential for development of both SAR and ISR in plants $[54,55]$.

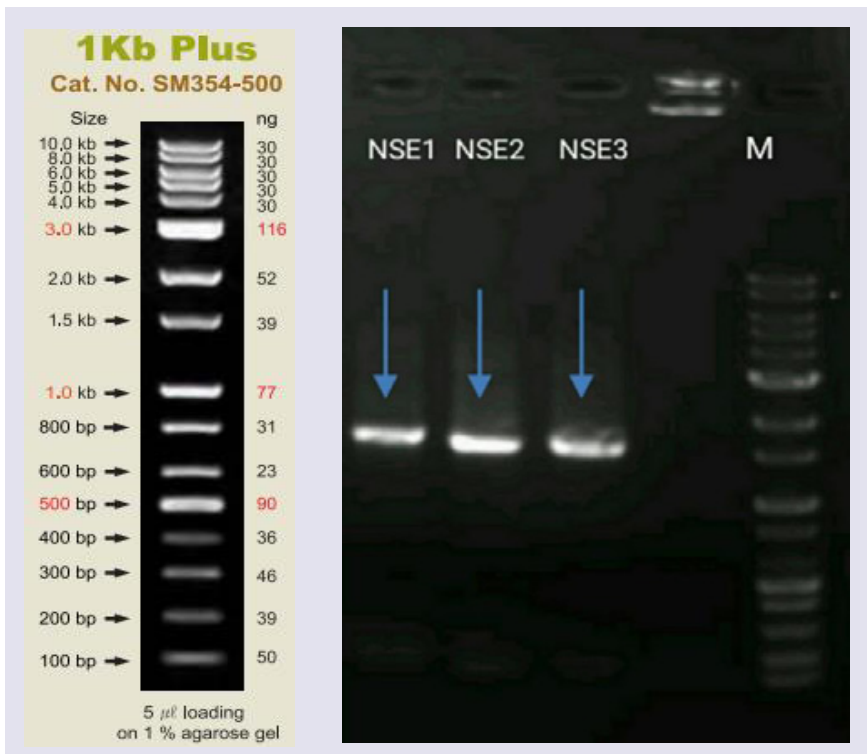

Figure 4: Agarose gel electrophoresis after 16s rDNA-PCR amplification of three bacterial isolates. Lane $\mathrm{NSE}_{1}$ represents Bacillus Megaterium (MH142578), Lane NSE represents Acinetobacter Iwoffii (MH142579) and Lane $\mathrm{NSE}_{3}$ represents Acinetobacter Iwoffii (MH142580) respectively. Lane $\mathrm{M}$ represents the molecular size marker (1 kb leader).

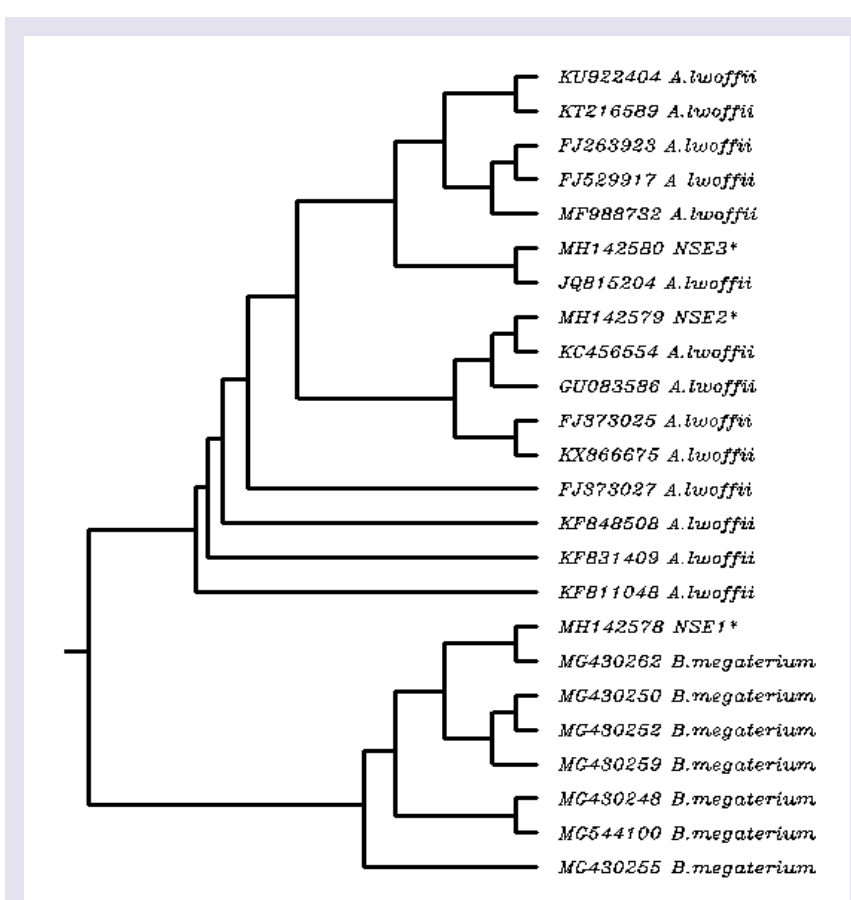

Figure 5: Phylogenetic analysis of bacterial isolates based on ITS region of geneomic rDNA gene showing the relationship between our three isolates and 21 representative strains. The tree based on the clustal omega multiple sequence alignment programs. Rooted phylogentic tree (UPGMA). *MH142578: Bacillus Megaterium ( $\mathrm{NSE}_{1}$ ), MH142579: Acinetobacter Iwoffii $\left(\mathrm{NSE}_{2}\right)$ and $\mathrm{MH1}$ 142580: Acinetobacter /woffii $\left(\mathrm{NSE}_{3}\right)$.

Biological control of plant pathogens has been the focus of many studies in plant protection that search for alternative or complementary methods to the use of chemical pesticides. PGPR have captured the attention of many researchers because of the potential for developing 
Citation: Abdelaziz S, Hemeda NF, Belal EE, Serag AM. Isolation, Characterization and Genetic Studies on Isolates of Phosphate Solubilizing Bacteria in Egyptian Calcareous Soils. J Plant Biol Soil Health. 2019;6(1): 10.

\section{ISSN: 2331-8996}

Table 9: Genetic similarity percentage of 14 isolates of Acinetobacter /woffii and two isolates $\mathrm{NSE}_{2}$ and NSE ${ }_{3}$ with accession numbers (MH142579 and MH142580) based on ITS region of genomic 16s rDNA gene.

\begin{tabular}{|c|c|c|c|c|c|c|c|c|c|c|c|c|c|c|c|c|}
\hline & 1 & 2 & 3 & 4 & 5 & 6 & 7 & 8 & 9 & 10 & 11 & 12 & 13 & 14 & 15 & 16 \\
\hline 1 & 100 & 98.63 & 98.63 & 98.72 & 98.53 & 98.9 & 98.99 & 98.53 & 96.51 & 97.71 & 98.26 & 98.72 & 98.53 & 98.53 & 98.44 & 97.8 \\
\hline 2 & & 100 & 99.3 & 98.53 & 98.46 & 97.47 & 98.46 & 99.44 & 97.09 & 97.45 & 98.31 & 98.1 & 99.3 & 98.65 & 98.88 & 98.37 \\
\hline 3 & & & 100 & 97.3 & 98.81 & 97.21 & 98.47 & 97.92 & 96.91 & 96.6 & 97.49 & 97.63 & 98.45 & 98.8 & 98.41 & 98.45 \\
\hline 4 & & & & 100 & 98.67 & 97.56 & 97.29 & 97.17 & 97.54 & 97.15 & 97.98 & 97.08 & 98.95 & 98.5 & 97.65 & 98.52 \\
\hline 5 & & & & & 100 & 98.25 & 98.6 & 97.97 & 97.27 & 97.2 & 97.97 & 98.04 & 98.1 & 97.67 & 98.39 & 98.73 \\
\hline 6 & & & & & & 100 & 97.91 & 96.44 & 97.36 & 97.21 & 96.86 & 97 & 97.89 & 97.67 & 97.14 & 98.23 \\
\hline 7 & & & & & & & 100 & 97.15 & 97 & 96.74 & 97.28 & 97.42 & 98.6 & 98.42 & 97.99 & 98.66 \\
\hline 8 & & & & & & & & 100 & 97.09 & 96.81 & 97.7 & 97.01 & 99.16 & 99.85 & 98.2 & 97.74 \\
\hline 9 & & & & & & & & & 100 & 98.18 & 97.73 & 97.27 & 97.09 & 97.09 & 97.09 & 96.91 \\
\hline 10 & & & & & & & & & & 100 & 97.28 & 96.52 & 97.68 & 97.9 & 97.29 & 98.23 \\
\hline 11 & & & & & & & & & & & 100 & 97.14 & 98.17 & 98.27 & 97.56 & 98.59 \\
\hline 12 & & & & & & & & & & & & 100 & 97.96 & 98.12 & 97.56 & 98.02 \\
\hline 13 & & & & & & & & & & & & & 100 & 99.02 & 98.95 & 98.45 \\
\hline 14 & & & & & & & & & & & & & & 100 & 98.87 & 97.45 \\
\hline
\end{tabular}

1:|MH142579|NSE2*, 2:|KU922404|A.Iwoffii, 3:|FJ373027| A.Iwoffii, 4:|KF831409|A.Iwoffii, 5: KC456554|A.Iwoffii, 6:|GU083586|A.Iwoffii, 7:|FJ373025|A./woffii, 8:|KT216589|A.Iwoffii, 9:|MH142580|NSE3*, 10: KF811048|A.Iwoffii, 11: JQ815204|A.Iwoffii, 12:|KF848508|A.Iwoffii, 13:FJ529917|A.Iwoffii, 14:|FJ263923|A.Iwoffii, 15: |MF988732|A.Iwoffii and 16: |KX866675|A.Iwoffii

these bacteria as inocula for plant disease control. The PGPR under most scrutiny for potential use in agriculture are those belonging to the genera Pseudomonas and Bacillus [56]. In the present work, of the 25 isolates showed antifungal activity12 (37.5\%) 17 (53.12\%), 20 (62.5\%) and 17 (53.12\%), against Py. ultimum R. solani F. oxysporum $P$. infestans respectively.

We can summarize the extremophiles and the extremoduric properties in some abbreviations as mentioned by Satyanarayana in the following: Psychrophiles, Thermophiles, Acidophiles, Alkalophiles, Baraophiles, Halophiles, Oligocarophiles, Oligonitrophiles, Radiation resistant, Methanogenic, Toxitolerant, Xerophiles and Organic Solvents Tolerant [57].

In the present study Five strains were chosen because they proved to have the higher activities in the different characters studied (IAA, $\mathrm{SA}, \mathrm{N}_{2}$-fixition ...etc) according to assessment values, All isolates were capable of growing at high temperature $\left(50^{\circ} \mathrm{C}\right)$ and $\mathrm{pH} 7.0$ producing observable growth in absence of salt after 24 hours incubation period. This phenomenon was also observed when the $\mathrm{pH}$ increased to 10.0 but temperature was at $30{ }^{\circ} \mathrm{C}$ in absence of salt but the growth was pronounced after 48 hours, in all strains tested. In presence of $15 \%$ salt at $\mathrm{pH} 10.0$ and $50{ }^{\circ} \mathrm{C}$ the picture seemed to somewhat different as three strains only were capable of producing observable growth. They were strains No NSE, $\mathrm{NSE}_{2}$ and $\mathrm{NSE}_{3}$ after 48 hours incubation period. All the three isolates ( $\mathrm{NSE}_{1}, \mathrm{NSE}_{2}$ and $\mathrm{NSE}_{3}$ ) showed an inhibitory (in vitro) against the test fungi. The three strains had the same efficiency whether in extreme or in normal conditions.

Molecular studies for the three bacterial isolates with its region of genomic rDNA gene showed band with approximately size 1500 bp using 16s rDNA - PCR two different bacterial genera, Bacillus and Acinetobacter showed closed phylogenetic tree between two isolates of Acinetobacter lwoffii, $\mathrm{NSE}_{2}$ and $\mathrm{NSE}_{3}$ and other subunit with $\mathrm{NSE}_{1}$ from Bacillus megaterium. It means that there are relationships between the two bacterial isolates (Acinetobacter lwoffii, $\mathrm{NSE}_{2}$ and $\mathrm{NSE}_{3}$ ) and 14 representative strains, and there are relationships between the one bacterial isolate (Bacillus megaterium $\mathrm{NSE}_{1}$ ) and 7 representative strains.

The results of cluster analysis (Similarity index) showed that the highest similarity value 99.44 observed between 2 (KU922404) A. Iwoffii and 99.85 between 8 (KT216589) A. lowoffii, 99.85 between 8 KT216589) A. Iwoffii and 14 (Fj263923) A.lwoffii. The Lowest similarity was 96.51 between 1 (MH142579) $\mathrm{NSE}_{2}$ and 9 (MNH142580) as shown in (Tables 8 and 9).

\section{Conclusion}

Considerable research efforts are underway globally to exploit the potential of Phosphate Solubilizing Bacteria (PSB) as alternative for chemical pesticides and chemical fertilizers. The main objective of this thesis was to find strains of Phosphate Solubilizing Bacteria (PSB), have broad spectrum of plant growth-promoting abilities and antagonistic potential against phytopathogenic fungi, which could be used as safe alternative for the overuse of harmful agrochemicals. In general, The most three effective isolates were identified as Bacillus megaterium MH142578, Acinetobacter lwoffi MH142579 and Acinetobacter lwoffii MH142580 which have plant growth-promoting abilities and antagonistic potential against phytopathogenic fungi involved on anther proceeding study.

\section{References}

1. Pradhan N and Sukla LB (2005) Solubilization of inorganic phosphate by fungi isolated from agriculture soil. African J Biotechnol 5.

2. Guiñazú LB, Andrés JA, Del Papa MF, Pistorio M, Rosas SB (2010) Response of alfalfa (Medicago sativa L.) to single and mixed inoculation with phosphatesolubilizing bacteria and Sinorhizobium meliloti. Biol Fert Soils 46: 185-190.

3. Yu X, Liu X, Zhu T, Liu G, Mao C (2011) Isolation and characterization of phosphate-solubilizing bacteria from walnut and their effect on growth and phosphorus mobilization. Biol Fert Soils 47: 437-446.

4. Khosro Mohammadi, Yousef Sohrabi (2012) Bacterial biofertilizers for sustainable crop production: A REVIEW. ARPN J Agr Biological Sci 7: 307315

5. Gyaneshwar P, Naresh Kumar G, Parekh LJ, Poole PS (2002) Role of soil 
Citation: Abdelaziz S, Hemeda NF, Belal EE, Serag AM. Isolation, Characterization and Genetic Studies on Isolates of Phosphate Solubilizing Bacteria in Egyptian Calcareous Soils. J Plant Biol Soil Health. 2019;6(1): 10.

microorganisms in improving $\mathrm{P}$ nutrition of plants. Plant and Soil 245: 83-93.

6. Hao X, Cho CM, Racz GJ, Chang C (2002) Chemical retardation of phosphate diffusion in an acid soil as affected by liming. Nutr Cycl Agroecosys 64: 213224

7. Shahid M, Khan MS (2017) Assessment of glyphosate and quizalofop mediated toxicity to greengram [Vigna radiate (L.) Wilczek], stress abatement and growth promotion by herbicide tolerant Bradyrhizobium and Pseudomonasspecies. Int J Curr Microbiol App Sci 6: 3000-3001.

8. Richardson AE (2001) Prospects for using soil microorganisms to improve the acquisition of phosphate solubilization. 69-75

9. Alam SS, Ayub KN, Rashid M (2002) In vitro solubilization of inorganic phosphate by phosphate solubilizing microorganism (PSM) from maize rhizosphere. Intl J Agric Biol 4: 454-458.

10. Antoun H, Kloepper JW (2001) Plant growth-promoting rhizobacteria (PGPR), In: Encyclopedia of Genetics, Brenner S, Miller JH (Eds) Academic Press, N.Y., pp.1477-1480.

11. Klute A (1986) Methods of Soil Analysis. Part-1: Physical and Mineralogical Methods. 2nd Edition. American Society of Agronomy, Madison, Wisconsin, USA.

12. Page AL, Miller RH, Keeney DR (1982) Methods of Soil Analysis. Part-1: Chemical and Microbiological Properties. 2nd Edition. American Society of Agronomy, Madison, Wisconsin, USA.

13. Chapman HD, Pratt PF (1961) Method of analysis for soils and water. University of California, Div. Agric. Sci., USA

14. Jackson ML (1956) Soil analysis. Adv. Course. Fourth print. Dept. of Soil Sci. Univ. of Wisconsin, Madison. WI.

15. Black CA, Evans DD, White JL, Ensminger LE, Clark FE (1965) Methods of soil analysis" part 1: physical and mineralogical properties. Published by the American Society of Agronomy. Madison, Wisconsin, USA.

16. Olsen SR, Sommers LE (1982) Phosphorus In: Page, A.L., Miller, R.H. and Keeney, D.R. (Eds.). Methods of Soil Analysis. Part 2. 2nd ed. ASA and SSSA Publisher, Madison. 403-430.

17. Lindsay WL, Norvell WA (1978) Development of a DTPA soil test for zinc iron, manganese and copper. Soil Sci Soc Am J 42: 421-428.

18. Pikovskaya RI (1948) Mobilization of phosphates in soil in connection with the vital activities of some microbial species. Microbiology 17: 362-370.

19. Defreitas JR, Banerjee MR, Gemida JJ (1997) Phosphate solubilizing rhizobacteria enhance the growth and yield but not phosphorus uptake of canola (Brassica napus L.). Biol Fertil Soils 24: 358-364.

20. Edi-Premono M, Moawad MA, Vleck PLG (1996) Effect of phosphate solubilizing Pseudmonasputida on the growth of maize and its survival in the rhizosphere. Indonesian J Crop Sci 11: 13-23.

21. Loper JE, Schroth MN (1986) Influence of bacterial sources of indole-3-acetic acid on root elongation of sugar beet. Phytopathology 76: 386-389.

22. Schwyn B, Neilands JB (1987) Universal chemical assay for detection and determination of siderophores. Anal Biochem 160: 47- 56

23. Pallai R (2005) Effect of plant growth-promoting rhizobacteria on canola (Brassica napus. L) and lentil (Lens culinaris. Medik) plants. Thesis, Master of Science, Department of Applied Microbiology and Food Science, University of Saskatchewan, Saskatoon. Canada.

24. Meyer JM, Abdallah MA (1978) The fluorescent pigment of Pseudomonas fluorescens: biosynthesis, purification and physicochemical properties. Journal of General Microbiology 10: 319-328.

25. Leeman M, Denouden FM, van Pelt JA, Cornelissen C, Matamala Garros A, et al. (1996) Suppression of Fusarium wilt of radish by co-inoculation of fluorescent Pseudomonas spp. and root-colonizing fungi. Eur J Plant Patho 102: 21-31.

26. Andro T, Chambost JP, Kotoujansky A, Cattaneo J, Bertheau Y, et al. (1984) Mutants of Erwiniachrysanthemi defective in secretion of pectinase and cellulase. Journal of Bacteriol 160: 1199-1203.

27. Frändberg E, Schnürer J (1998) Antifungal activity of chitinolytic bacteria isolated from airtight stored cereal grain. Can J Microbiol 44: 121-127.

28. Haahtela K, Helander I, Nurmiaha-Lassila EL, Sundman V (1983a) Morphological and physiological characteristics and lipopolysaccharide composition of N2-fixing (C2H2-reducing) root-associated Pseudomonas sp. Can J Microbiol 29: 874-880.

29. Haahtela K, Kari K, Sundman V (1983b) Nitrogenase activity (Acetylene Reduction) of root-associated, cold- climate Azosperillum, Enterobacter Klabsilla, and Pseudomonas species. Appl Environ Microbiol 45: 563-570.

30. Cattelan AJ, Hartel PG, Fuhramnn JJ (1999) Screening for plant growthpromoting to promote early soybean growth. Soil Sci Soc Am J 63: 1670 1680.

31. Koch E (1997) Screening of rhizobacteria for antagonistic activity against Pythium ultimum on cucumber and kale. J Plant Dis Prot 104: 353-361.

32. Miller CS, Handley KM, Wrighton KC, Frischkorn KR, Thomas BC, et al. (2013) Short-read assembly of full-length $16 \mathrm{~S}$ amplicons reveals bacterial diversity in subsurface sediments. PloS one 8: e56018.

33. Altschul SF, Madden TL, Schaffer AA, Zhang J, Zhang Z, et al. (1997) Gapped BLAST and PSI-BLAST: a new generation of protein database search programs. Nucleic Acids Res 3389-3402.

34. Benson DA, Boguski MS, Lipman DJ, Ostell J, Oullette BF, et al. (1999) GenBank. Nucleic Acids Res 8: 12-17.

35. Thompson JD, Higgins DJ, Gibson TJ (1994) CLUSTAL W: improving the sensitivity of progressive multiple sequence alignment through sequence weighting, positive specific gap penalties and weight matrix choice. Nucleic acids Res 22: 4673-4688.

36. Krechel A, Faupel A, Hallmann J, Ulrich A, Berg G (2002) Potato-associated bacteria and their antagonistic potential towards plant-pathogenic fungi and the plant-parasitic nematode Meloidogyne incognita (Kofoid and White) Chitwood. Can J Microbiol 48: 772-786.

37. Cheng K, Lu FP, Li M, Liu LL, Liang XM (2010) Purification and biochemical characterization of a serine alkaline protease TC4 from a new isolated Bacillus alcalophilus TCCC11004 in detergent formulations. African J Biotechnol 9.

38. Jones DL, Darrah PR (1994) Role of root derived organic acids in the mobilization of nutrients from the rhizosphere. Plant Soil 166: 247-257.

39. Toro M, Azcon R, Barea JM (1997) Improvement of arbuscularmycorrhiza development by inoculation of soil with phosphate-solubilizing rhizobacteria to improve rock phosphate bioavailability (sup32) P and nutrient cycling. Appl Environ Microbiol 63: 4408-4412.

40. Altschul SF, Madden TL, Schaffer AA, Zhang J, Zhang Z, et al. (1997) Gapped BLAST and PSI-BLAST: a new generation of protein database search programs. Nucleic Acids Res 3389-3402.

41. Vessey JK (2003) Plant growth promoting rhizobacteria as biofertilizers. Plant and Soil 255: 571-586.

42. Hafeez FY, Yasmin S, Ariani D, Mehboob UR, Zafar RY, et al. (2006) Plant growth-promoting bacteria as biofertilizer. Agron Sust Develop 26: 143-150.

43. Shahid M, Ahmed B, Khan MS (2018) Evaluation of microbiological management strategy of herbicide toxicity to greengram plants. Biocatalysis and Agricultural Biotechnology 14: 96-108.

44. Adesemoye AO, Torbert HA, Kloepper JW (2009) Plant growth-promoting rhizobacteria allow reduced application rates of chemical fertilizers. Microbial Ecol 58: 921-929.

45. Cattelan AJ, Hartel PG, Fuhramnn JJ (1999) Screening for plant growthpromoting to promote early soybean growth. Soil Science Society of America Journal 63: 1670-1680

46. Chen YP, Rekha PD, Arunshen AB, Lai WA, Young CC (2006) Phosphate solubilizing bacteria from subtropical soil and their tricalcium phosphate solubilizing abilities. Appl Soil Ecol 34: 33-41. 
Citation: Abdelaziz S, Hemeda NF, Belal EE, Serag AM. Isolation, Characterization and Genetic Studies on Isolates of Phosphate Solubilizing Bacteria in Egyptian Calcareous Soils. J Plant Biol Soil Health. 2019;6(1): 10.

47. Andrade G, Esteban E, Velasco L, Lortie MJ, Bedmar EJ (1997) Isolation and identification of $\mathrm{N} 2$-fixing microorganisms from the rhizoplane of Capparisspinosa (L.). Plant and Soil 197: 19-23.

48. El-Sayed WS, Akhkha A, El-Naggar MY, Elbadry M (2014) Invitroantagonisticactivity plant growth promoting traits and phylogenetic affiliation of rhizobacteria associated with wild plants grown in arid soil. Front Microbiol 5: 1-11.

49. Kloepper JW, Leong J, Teintze M, Schroth MN (1980b) Pseudomonas siderophores: A mechanism explaining disease-suppressive soils. Current Microbiology 4: 317-320.

50. Leong J (1986) Siderophores: their biochemistry and possible role in the biocontrol of plant pathogens. Ann Rev Phytopathol 26: 187-209.

51. Yehuda Z, Shenker M, Romheld V, Marschner H, Hadar Y, et al. (1996) The role of legend exchange in the Uptake of Iron from microbial siderophores by gramineous plants. Plant Physiol 112: 1273-1280.

52. Leeman M, van Pelt JA, Hendrickx MJ, Scheffer RJ, Bakker PAHM (1995a.)
Biocontrol of fusarium wilt of radish in commercial greenhouse trials by seed treatment with Pseudomonas fluorescens WCS374. J Phytopathology 85: 1301-1305.

53. De Mayer G, Höfte M (1997) Salicylic Acid Produced by the rhizobacterium Pseudomonas aeruginosa 7NSK2 induces resistance to leaf Infection by Botrytis cinerea on bean. Phytopathology 86: 588-593.

54. van Loon LC, Bakker PA, Pieterse CM (1998) Systemic Resistance Induced by rhizosphere bacteria. Annu Rev Phytopathol 36: 453-483.

55. Zhang S, Moyne L, Reddy MS, Kloepper JW (2002) The role of salicylic acid in induced systemic resistance elicited by plant growth-promoting rhizobacteria against blue mold of tobacco. Biocontrol 25: 288-296.

56. Powell KA, Rhodes DJ (1994) Strategies for the progression of biological fungicides into field evaluation. British Crop Protection Council Symposium Proceedings, BCPC Monograph. No. 59: 307-315.

57. Satyanarayana T, Raghukumar C, Shivaji S (2005) Extremophilic microbes: Diversity and perspectives. Curr Sci 89: 78-90. 